\title{
Gobi agriculture: an innovative farming system that increases energy and water use efficiencies. A review
}

\author{
Jianming Xie ${ }^{1,2} \cdot$ Jihua $\mathrm{Yu}^{1,2} \cdot$ Baihong Chen ${ }^{1,2} \cdot$ Zhi Feng $^{1,2} \cdot$ Jian Lyu ${ }^{1,2} \cdot$ Linli Hu $^{1,2} \cdot$ Yantai Gan $^{3}$ (D) \\ Kadambot H. M. Siddique ${ }^{4}$
}

Accepted: 4 October 2018 / Published online: 29 October 2018

(C) The Author(s) 2018

\begin{abstract}
In populated regions/countries with fast economic development, such as Africa, China, and India, arable land is rapidly shrinking due to urban construction and other industrial uses for the land. This creates unprecedented challenges to produce enough food to satisfy the increased food demands. Can the millions of desert-like, non-arable hectares be developed for food production? Can the abundantly available solar energy be used for crop production in controlled environments, such as solar-based greenhouses? Here, we review an innovative cultivation system, namely "Gobi agriculture." We find that the innovative Gobi agriculture system has six unique characteristics: (i) it uses desert-like land resources with solar energy as the only energy source to produce fresh fruit and vegetables year-round, unlike conventional greenhouse production where the energy need is satisfied via burning fossil fuels or electrical consumption; (ii) clusters of individual cultivation units are made using locally available materials such as clay soil for the north walls of the facilities; (iii) land productivity (fresh produce per unit land per year) is 10-27 times higher and crop water use efficiency 20-35 times greater than traditional open-field, irrigated cultivation systems; (iv) crop nutrients are provided mainly via locallymade organic substrates, which reduce synthetic inorganic fertilizer use in crop production; (v) products have a lower environmental footprint than open-field cultivation due to solar energy as the only energy source and high crop yields per unit of input; and (vi) it creates rural employment, which improves the stability of rural communities. While this system has been described as a "Gobi-land miracle" for socioeconomic development, many challenges need to be addressed, such as water constraints, product safety, and ecological implications. We suggest that relevant policies are developed to ensure that the system boosts food production and enhances rural socioeconomics while protecting the fragile ecological environment.
\end{abstract}

Keywords Cultural substrate $\cdot$ Environmental footprint $\cdot$ Food security $\cdot$ Gobi Desert $\cdot$ Clear energy $\cdot$ Sustainability

Jihua Yu

yujihua@gsau.edu.cn

$\triangle$ Yantai Gan

yantai.gan@canada.ca

1 Gansu Provincial Key Laboratory of Aridland Crop Sciences, Gansu Agricultural University, Lanzhou 730070, China

2 College of Horticulture, Gansu Agricultural University, Lanzhou 730070, China

3 Agriculture and Agri-Food Canada, Swift Current Research and Development Centre, Swift Current, SK S9H 3X2, Canada

4 The UWA Institute of Agriculture and School of Agriculture \& Environment, The University of Western Australia, Perth, WA 6001, Australia

\section{Contents}

1. Introduction

2. A brief review of infrastructure of Gobi-land systems

3. Scientific advancement of Gobi-land cultivation systems

3.1 Increased crop productivity

3.2 Improved water use efficiency

3.3 Improved nutrient use efficiency

3.4 Increased energy use efficiency

3.5 Environmental benefits

3.6 Ecological benefits

3.7 Effects on the stability of rural communities

4. Major challenges

4.1 Water resource constraints

4.2 Fragile ecological environments

4.3 Labor resource constraints 
4.4 Economic sustainability

4.5 Product quality and health

5. Setting policies for sustainable development in Gobi land systems

5.1 Balance between exploration and protection

5.2 Develop systematic measures for water use and water saving

5.3 Strengthen agro-technology innovation

5.4 Regulate the food chain

5.5 Cultivate professional farmers

5.6 Establish a sound social service system

6. Conclusions

Acknowledgments

References

\section{Introduction}

Arable land for agriculture is a limited resource (Liu et al. 2017). In countries with fast economic development, such as China, India, and Africa, much arable land has been converted to industrial use (Çakir et al. 2008; Xu et al. 2000). Due to rapid urbanization that competes for land with agriculture (Zhang et al. 2016; Mueller et al. 2012), there is an unprecedented challenge for increasing crop production to satisfy the dietary needs and preferences of the growing human population (Godfray et al. 2010). It is possible that developed countries with large areas of arable land, such as Australia, Canada, and the USA, could convert grassland areas to cropland for world grain markets. However, doing so may accelerate the loss of carbon reserves and have significant, negative impacts on the environment (Godfray 2011).

In many arid and semiarid environments, there are vast areas of "Gobi land" (defined as non-arable land), including 1.95 million hectares of desert-type land in the six provinces of northwestern China (Liu et al. 2010). China is making a concerted effort to develop this Gobi land for food production using an innovative cropping system, called "Gobi agriculture." We defined this cultivation system as "A cultivation system with a cluster of locally-constructed, solar-powered plastic greenhouse-like cultivation units for the production of high-yielding, high-quality fresh produce (vegetables, fruits and ornamentals) in an effective, efficient and economical manner" (Xie et al. 2017). In some sophisticated cluster systems, the climatic conditions in the individual units can be monitored using data loggers. Unlike conventional greenhouses or glasshouses where heating and cooling (two major costs involved in greenhouse production) are usually provided by burning fossil fuels (diesel, fuel oil, liquid petroleum, gas) that increase $\mathrm{CO}_{2}$ emissions, or using electric heaters that consume more energy (Hassanien et al. 2016; Wang et al. 2017), "Gobi agriculture" systems rely entirely on solar energy for heating, cooling, and the conversion of natural energy into plant biomass.

In recent years, the use of Gobi land for food production has been rapidly evolving in China (Zhang et al. 2015). In the northwest regions, Gobi land cultivation systems produce a large proportion of the vegetables consumed in the region. This system is playing a vital role in ensuring food security, increasing socioecological sustainability, and enhancing rural community viability. Many consider this Gobi land agriculture a "newfound land" cultivation system. A significant feature of the system is the opportunity for food production on once unproductive land. This innovative cultivation system may be a revolutionary step towards modern agriculture. However, there is a lack of information on the scientific advancement of Gobi-land cultivation systems. Many questions remain unanswered: Will this system sustainably evolve into a major vegetable production industry? How will the Gobi land cultivation system affect the eco-environment in the long term? Can this "made-in-China" cultivation model apply to other arid zones with dwindling arable land areas, such as northern Kazakhstan (Kraemer et al. 2015), Siberia (Halicki and Kulizhsky 2015), and central to northern African regions (de Grassi and Salah Ovadia 2017)?

With these questions in mind, we conducted a comprehensive literature review on recent developments and key research findings regarding the cultivation system. The objectives of this paper were to (i) highlight the scientific advancements of Gobi-land cultivation systems adopted in northern China, including crop productivity, water use efficiency (WUE), nutrient and energy use characteristics, and potential ecological and environmental impacts; (ii) discuss major challenges facing the system, such as the availability of water for irrigation, quality and safety of the produce, and the potential impact on rural community stability and development; and (iii) provide suggestions on policy setting and research priorities for healthy exploration and long-term sustainable development of Gobi land cultivation systems.

\section{A brief review of infrastructure of Gobi land systems}

To understand how the Gobi land cultivation system functions, we have provided a brief description of their design, engineering, and construction. More detail on the infrastructure is in a recent review (Xie et al. 2017). The Gobi land cultivation system is established on uncultivated Gobi land where traditional crop production is not possible. Gobi land facilities are constructed in "clusters" of individual production units. A typical clustered facility consists of several (up to hundreds) individual cultivation units or houses (Fig. 1a). The microclimatic conditions in each cultivation unit are monitored by a centralized control center where remote sensors, 
Fig. 1 A typical clustered facility established on the Gobi land in northwestern China; the system consists of (a) several (up to hundreds) of individual cultivation units, and (b) microclimatic conditions in each cultivation unit are monitored through a centralized controlling center
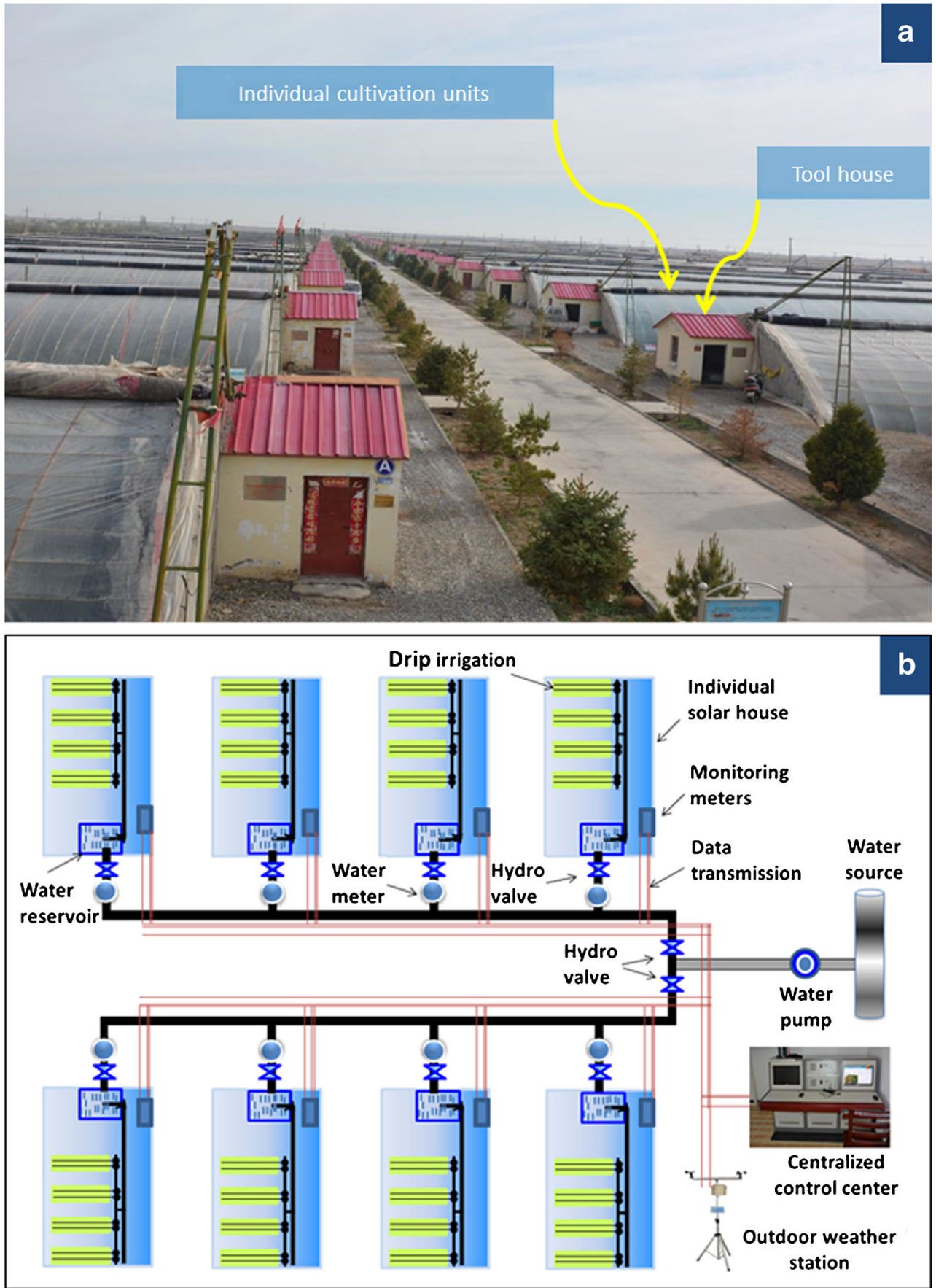

data collectors, and information transmitters are connected to a computer system (Fig. 1b). Microclimatic conditions, such as air temperature and humidity, can be adjusted in some cultivation units, while other monitoring systems allow automatic fertigation. Some advanced technologies such as the Internet of objects (Wang and Xu 2016) or Internet of things (Li et al. 2013) can be installed in the control center to provide more accurate readings of the microclimatic data transmitted from individual cultivation units. However, these have not been widely implemented due to the high cost.
A typical cultivation unit within a clustered facility is oriented east-west and has three walls on the north, east, and west sides of the structure. The south side of the structure is a tilted roof supported by a steel frame and covered with transparent thermal plastic film (Fig. 2). The roof is appropriately tilted to ensure effective light transmittance during the day (Zhang et al. 2014). Energy from the sun is stored in the thermal mass of the walls and released as heat at night. During winter, the roof is covered with homemade straw mats at each night to maintain the internal temperature (Tong et al. 2013). 


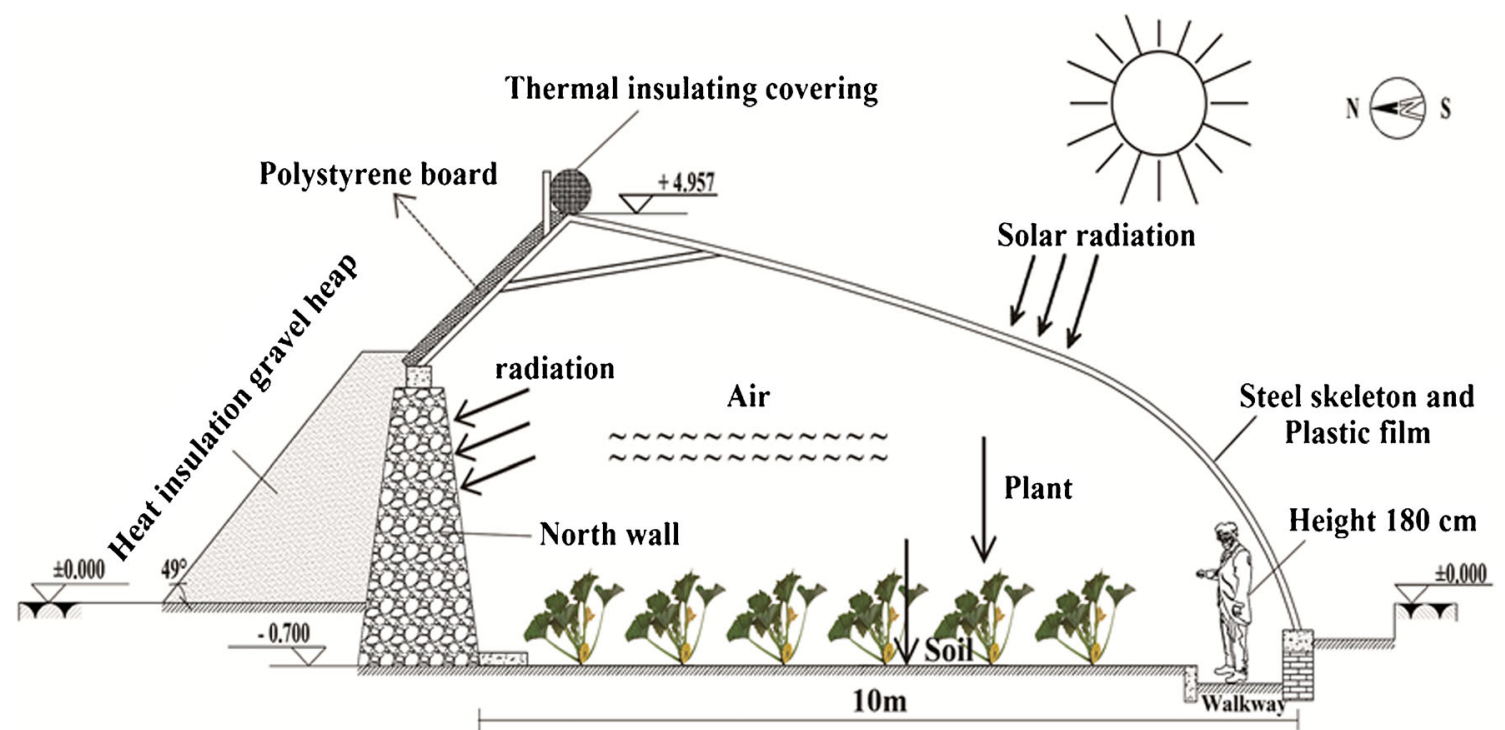

Fig. 2 A typical cultivation unit in northwest China that has a south-facing roof supported by a steel frame and covered with transparent thermal plastic film on the top. Many such cultivation units are clustered together within a controlling center

A critical component of each cultivation unit is the north wall that is built from locally available materials such as clay bricks (Wang et al. 2014), crop straw blocks (Zhang et al. 2017), common bricks with styrofoam (Xu et al. 2013), fly ash masonry units (Xu et al. 2013), clay blocks mixed with cement mortar (Chen et al. 2012), rammed earth (Guan et al. 2013), or raw soil incorporated with concrete blocks. In some units, the north wall is constructed from "phase-changing material" to optimize heat storage and exchange, and, therefore, reduce temperature fluctuations for plant growth (Guan et al. 2012).

One of the significant differences between Gobi land clustered facilities and traditional greenhouses or glasshouses is the power source. Each cultivation unit in the clustered Gobi land system is powered entirely by solar energy. Solar radiation is absorbed by the north wall during the day and released at night. Unused energy during the day is an active energy source at night. A "water-curtaining" system is typically used to provide supplementary heat during winter nights, where a small section of the ground within the unit is filled with water to use as heat-exchanging media (Xie et al. 2017). During the day, water circulates and passes through the water-absorbing curtains, with excess heat from solar radiation stored in the water body; at night, the warm water circulates and passes through water curtains with heat released to the air inside the unit. The effectiveness of energy storage in the "water-curtaining" system depends on many factors, such as direct solar radiation, isotropic diffuse solar radiation from the sky, atmospheric transparency, and heat transmittance from the plastic film on the roof (Han et al. 2014). With the evolution of the cultivation systems, more sophisticated heating systems are being developed for improved heat storage and release.

\section{Scientific advancement of Gobi land cultivation systems}

Gobi land cultivation systems differ from traditional openfield crop cultivation where crops are either rainfed or irrigated. They also differ from crop cultivation in conventional greenhouses or glasshouses where energy is mostly supplied by natural gas or electricity. Gobi land cultivation systems have unique features, some of which are highlighted below.

\subsection{Increased crop productivity}

Crops grown in Gobi land facilities are highly productive with significantly higher land use efficiency (i.e., crop yield per unit of land used) than traditional open-field cultivation. For example, the eastern region of the Hexi Corridor in Northwest China has a long-term (1960-2009) annual sunshine duration of $2945 \mathrm{~h}$, annual mean air temperature $7.2^{\circ} \mathrm{C}$, and frost-free period of 155 days (Chai et al. 2014c); the heat units are more than sufficient to produce one crop per year but insufficient to produce two crops per year under the traditional open-field systems. In the Gobi-land system, crops can be grown in most months or even year-round. Average annual crop yields over 5 years (2012-2016) in cultivation units at the Jiuquan Experimental Station were $34 \mathrm{t} \mathrm{ha}^{-1}$ for muskmelon (Cucumis melo L.), $66 \mathrm{t} \mathrm{ha}^{-1}$ for watermelon (Citrullus lanatus L.), $102 \mathrm{t} \mathrm{ha}^{-1}$ for hot pepper (Capsicum annuum, C. frutescens), $168 \mathrm{t} \mathrm{ha}^{-1}$ for cucumber (Cucumis sativus L.), and $177 \mathrm{t} \mathrm{ha}^{-1}$ for tomato (Solanum lycopersicum L.), which are 10-27 times higher than those in traditional openfield systems under the same climatic conditions (Xie et al. 2017). Similar results have been observed elsewhere in northern China, such as Wuwei district at the eastern end of the 
Hexi Corridor. These yield values were calculated on the land area occupied by the cultivation units, as well as the common areas shared by individual units within the same controlling system. The common areas are for input material transportation and product marketing.

\subsection{Improved water use efficiency}

One of the major challenges for agriculture in many arid and semiarid areas is water shortages. Saving water or improving WUE (crop yield per unit water supplied, expressed as $\mathrm{kg} \mathrm{ha}^{-1}$ yield $\mathrm{m}^{-3}$ water) in crop production is crucial for agricultural viability. Gobi land cultivation systems offer significant water-saving advantages, where crops use much less water than the same crop grown in traditional open-field systems. For example, over 4 years (2012-2015) of measurements in a Gobi land facility system in Jiuquan county, tomato required 385-466 mm total irrigation, seasonal evapotranspiration ranged from 350 to $428 \mathrm{~mm}$, and tomato fresh weights ranged from 86 to $152 \mathrm{t} \mathrm{ha}^{-1}$. Some major vegetable crops achieved high WUE ( $\mathrm{kg}$ fresh produce $\mathrm{m}^{-3}$ ), including 15-21 water for muskmelon, 17-23 for hot pepper, 22-28 for watermelon, 2835 for cucumber, and $35-51 \mathrm{~kg}$ for tomato. In this system, the WUE of tomato, for example, was 20-35 times greater than the same crops grown in arable land, open-field systems (Xie et al. 2017).

The mechanism for enhanced WUE in Gobi land systems is poorly understood. We suggest that the main contributing factors include the following: (a) the amount of irrigation applied to crops in Gobi land systems is based on plant requirements for optimal growth (Liang et al. 2014) which is predetermined and controlled via an installed water meter (Fig. 3a). Depending on the unit operator's knowledge and experience, a regulated deficit irrigation method is often used (Fig. 3b) that reduces irrigation amounts at the non-critical growth stages (Chai et al. 2014b). Mild deficit irrigation can
Fig. 3 Crops grown in facility systems have a high water use efficiency (WUE), largely due to (a) the amount of irrigation applied to crops is controlled using a water meter, (b) regulated deficit irrigation is often used to omit one or two irrigations at the non-critical growth stages, $(\mathbf{c})$ subsurface drip irrigation is used to save water, (d) plant rows are mulched to reduce soil surface evaporation, (e) between plant rows are also mulched to minimize soil evaporation, and (f) best agronomic practices are used for crop management in the facility

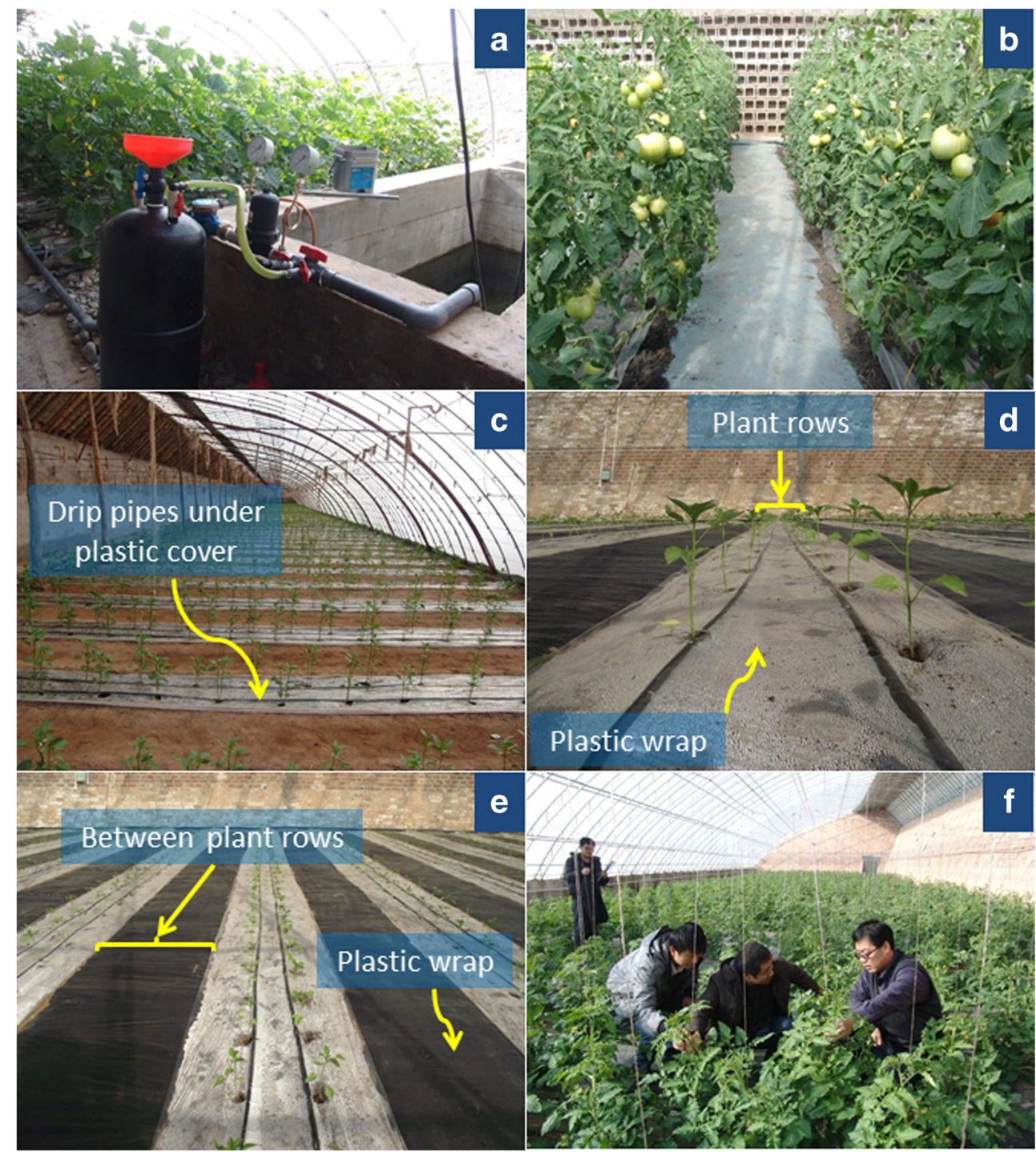


stimulate plant defense systems to enhance tolerance to drought stress (Romero and Martinez-Cutillas 2012; Wang et al. 2012). The magnitude of the effect of regulated deficit irrigation on crop performance varies with crop species and other factors (Chen et al. 2013; Wang et al. 2010); (b) irrigation techniques in Gobi land cultivation systems are constantly improving, such that subsurface drip irrigation (Fig. 3c) is now the most popular irrigation method; (c) various mulching methods are used to reduce soil surface water evaporation. The area of planting within the cultivation unit is usually covered with plastic film during the growing season (Fig. 3d), including the areas between plant rows (Fig. 3e). Reducing evaporation and increasing relative air humidity are likely the two most important factors in efficient water use; (d) a certain percentage of evaporated water from the soil surface is recycled within the cultivation unit because cultivation is in a relatively closed system; and (e) sophisticated agronomic practices are used for crop management in the cultivation unit (Fig. 3f), such as pruning branches to increase light penetration (Du et al. 2016), optimizing ventilation to balance $\mathrm{CO}_{2}$ for plant photosynthesis and disease incidence (Yang et al. 2017), and aerating the rooting zone post-irrigation for a few days to minimize soil evaporation ( $\mathrm{Li}$ et al. 2016); all of which help to increase crop yield and enhance WUE.

\subsection{Improved nutrient use efficiency}

Unlike traditional open-field cultivation where synthetic fertilizers are the major source of plant nutrients, organic material-such as crop straw, livestock manure and byproducts from the food industry, energy production processes, and human waste recycling - is the major nutrient source in Gobi land cultivation systems. The waste materials represent an alternative to commercial media used in conventional greenhouse production. To qualify as a substrate for Gobi land cultivation, organic materials must have the following characteristics (Fu et al. 2018; Fu and Liu 2016; Fu et al. 2017; Ling et al. 2015; Song et al. 2013): (i) low bulk density, high porosity, and high water-holding capacity; (ii) high cation exchange capacity and mineral nutrient content, and appropriate pH and EC; (iii) enhanced enzyme activity, usually accomplished by adding proper microorganism strains; (iv) slow degradation rate; and (v) be free of weed seeds and soilborne pathogens. The material type, processing method, degree of decomposition, and climatic conditions under which the substrates are produced may influence the physical, chemical, and biological properties of the organic material and, thus, substrate quality (Fu et al. 2017; Song et al. 2013).

The production of a typical homemade substrate involves several steps (Fig. 4a): (i) crop straw (such as maize) is collected from the traditional open-field production systems at local villages, transported to a site near the facility, chopped into $3-5 \mathrm{~cm}$ long pieces, before adding a low dose of nitrogen fertilizer ( $1.4 \mathrm{~kg} \mathrm{~N}$ per $1000 \mathrm{~kg}$ of dry maize straw) to adjust the $\mathrm{C}: \mathrm{N}$ ratio of the compost to about $15: 1$; (ii) about $1 \mathrm{~kg}$ of microorganism inoculation product per $1000 \mathrm{~kg}$ of organic material is added; (iii) the 1st stage of fermentation involves stacking the straw on the ground (e.g., $1.2 \mathrm{~m}$ high $\times 3.0 \mathrm{~m}$ wide on the bottom and $2.0 \mathrm{~m}$ wide on the top) before wrapping with plastic film; (iv) the temperature in the pile is monitored and water is added to maintain the moisture content at 60-65\% for optimum microorganism activity; (v) the second stage of fermentation requires disturbing the stack every 6 8 days and checking the temperature in the top $30 \mathrm{~cm}$. This periodical disturbance ensures that temperature and moisture are kept at an optimal level for microbial activity; and (vi) around day 32-34 after fermentation, the material is moved to a storage facility ready for use in facility cultivation. The homemade substrate is usually applied at $2-3 \mathrm{tha}^{-1}$ to cultivation areas within the cultivation unit and can be used for some years in cultivation before being replaced. The nutrient content of the substrates can be restored to a production level by adding outsourced nutrients (Fig. 4b). The straw material for the organic substrate is locally available, and most of the manufacturing steps use machines built in-house.

How the substrate nutrients are supplied to the crops varies between cluster facilities. Most growers in northwestern China use either (1) a trench system, where trenches (typically 0.4-0.6 m wide, $0.2-0.3 \mathrm{~m}$ deep, with $0.8-1.0 \mathrm{~m}$ between trenches oriented in a north-south direction) are made on the ground within the cultivation unit, edged with concrete, wood blocks or bricks, filled with substrate before planting (Fig. 5a), and covered with plastic film for the seedlings to grow through (Fig. 5b). Once constructed, the trenches can be used for continuous production for more than 20 years; or (2) whole-bag substrates, where the substrate is wrapped in individual plastic bags (typical dimension of a bag is $0.5 \mathrm{~m}$ diameter and $1.0 \mathrm{~m}$ long) in a closed micro-environment. Nutrients are released from the bags as the plants develop (Fig. 5c). Holes are made on the top of the bags for seed planting (Fig. 5d) and drip irrigation through the holes.

The two methods differ in their features. The trench method allows growers to easily add fertilizer to the substrates when needed. For some crops, such as watermelon, adding inorganic fertilizer is necessary to ensure high productivity. Some studies have shown that using organic manures along with inorganic fertilizer can increase crop yield but leaves nutrient surpluses in the soil and high nitrate-N concentrations in the topsoil (Gao et al. 2012). Other studies have indicated that the whole-bag approach is more productive than the trench system (Yuan et al. 2013) because the wrapped bags enable the substrate to be separated physically from the ground; thus, reducing the probability of contaminating substrates with soil-borne pathogens. Nonetheless, the physical and chemical properties of the substrate (in trenches or wrapped bags) can deteriorate with each cropping season (Song et al. 2013), 
Fig. 4 Homemade substrates to be used for nutrient supplies in cultivation units are generated mostly using organic materials. Procedures for making substrates at local sites include: (a) from crop straw to fermentation to the final substrate product, and (b) the potential reuse of the substrate after restoration of the nutrient content
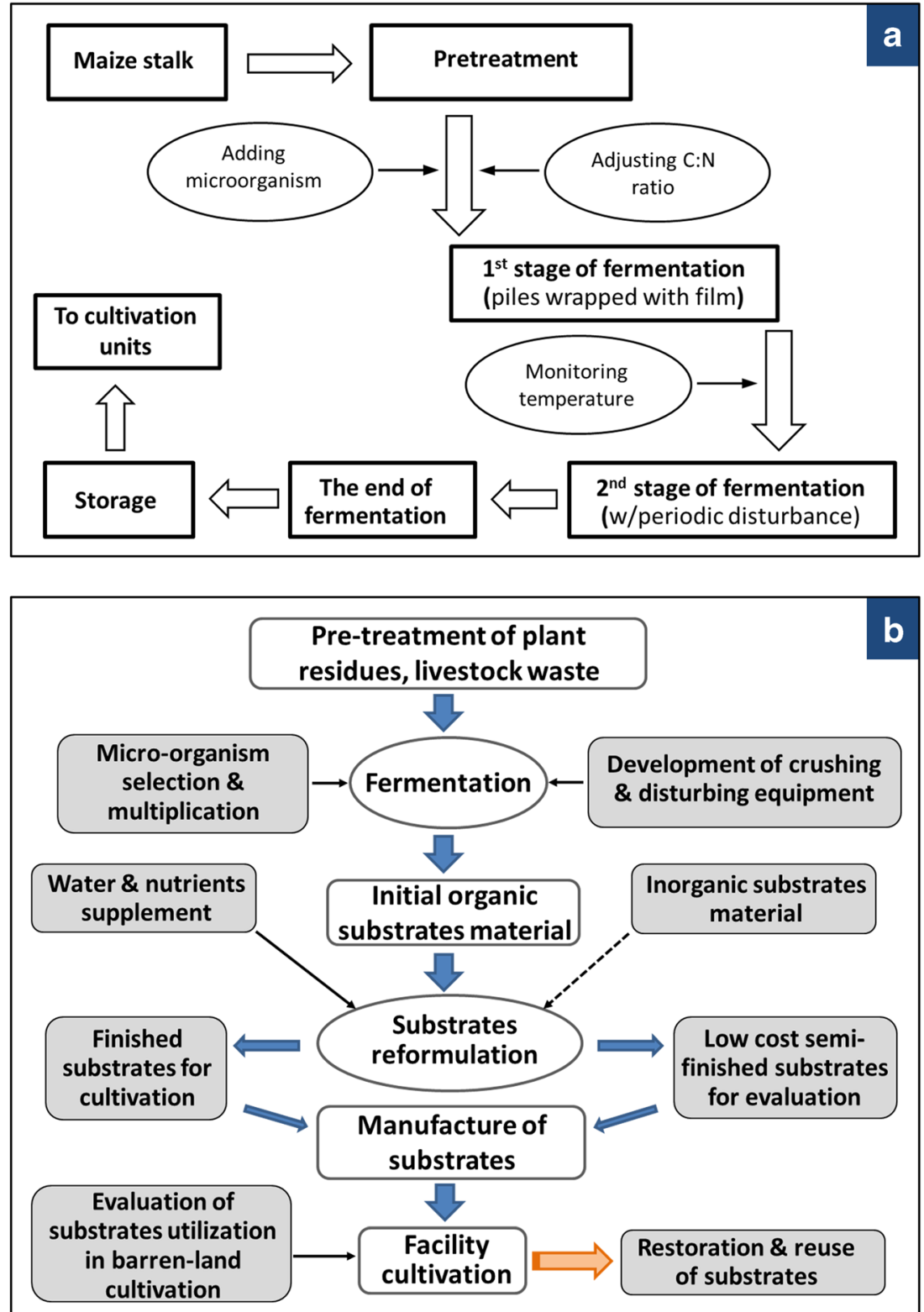

which reduces the power of nutrient supply (Song et al. 2013). Hence, substrate renewal is warranted.

\subsection{Increased energy use efficiency}

Gobi land cultivation systems are totally solar-energy based. The structure is designed to retain as much warmth as possible by using and storing energy from the sun. Daily sunshine duration, solar radiation intensity, and annual frost-free days are important for heating the cultivation units. The eastern to central Hexi Corridor, such as Wuwei county $\left(37^{\circ} 96^{\prime} \mathrm{N}, 102^{\circ}\right.$ $64^{\prime}$ E), Gansu Province, is a representative area where Gobiland clustered facilities are concentrated. An average $6150 \mathrm{MJ} \mathrm{m}^{-2}$ annual solar radiation and 156 frost-free days enable many types of vegetable crops to mature with high quality. To improve solar radiation use efficiency, the cultivation unit managers use various means to increase heat storage and enhance heat release, such as double-layers of black plastic film affixed to the north wall (Xu et al. 2014), heatpreserving color plates installed on the roof (Sun et al. 2013), shallow soil heat-absorbing systems to increase interior air temperature (Xu et al. 2014), and ground geotextile applied as groundcover to preserve heat. Also, solar heat pumps are used to regulate the water temperature in heat reservoir watertanks in some cultivation units (Zhou et al. 2016). More recently, heat preservative color plates have been placed on the top of the roof to increase heat absorption (Sun et al. 2013). In some of the sophisticated solar greenhouses in clustered facility cultivation, advanced solar technologies are used to improve thermal storage, photovoltaic power generation, and 
Fig. 5 Nutrient supply to crops in facility cultivation involves (a) making trenches and filling the trenches with substrates, and (b) covering the trenches with plastic film; alternatively (c) use of whole-bags of substrates and with (d) plants grown on the wholebags

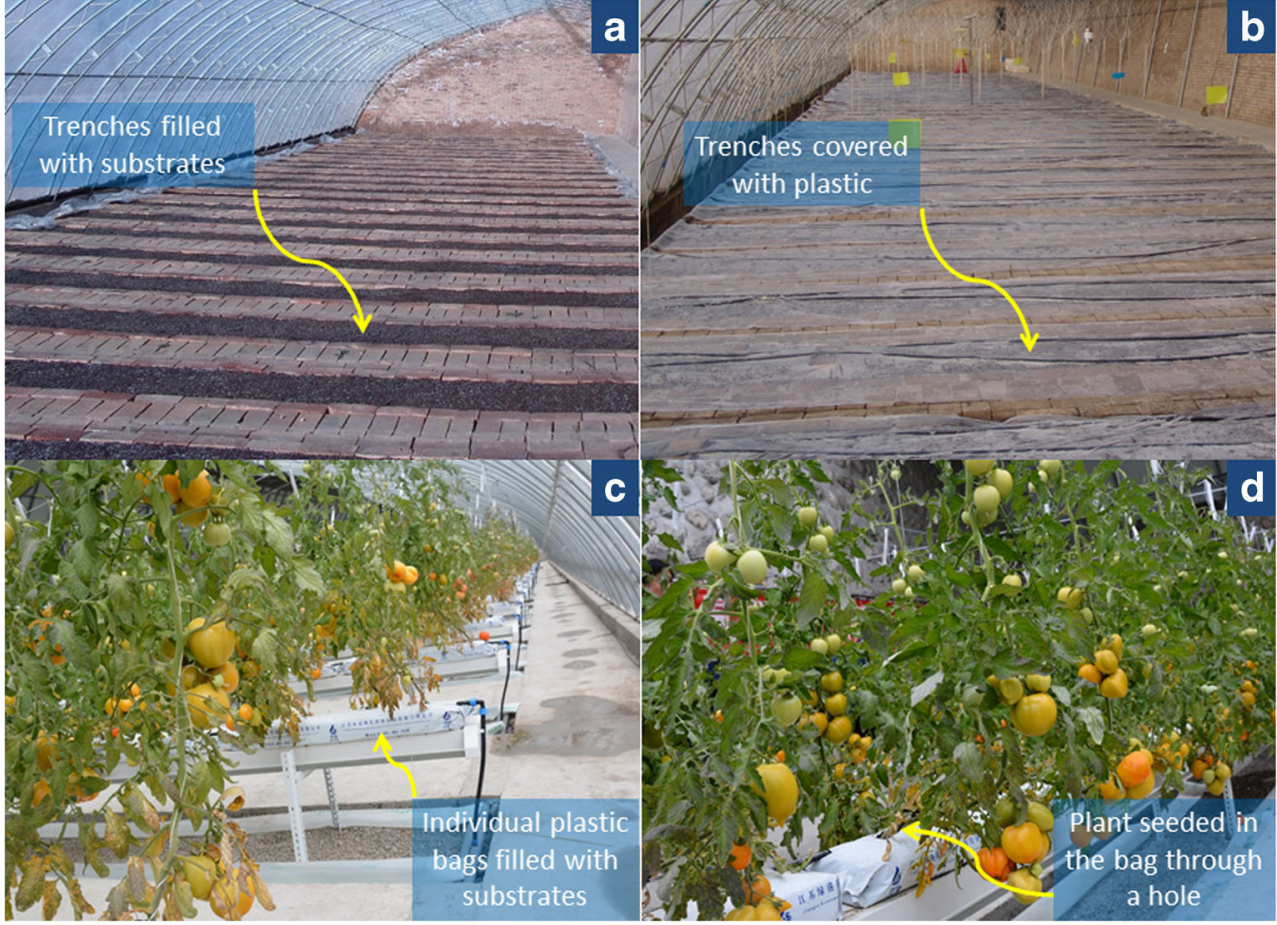

light utilization (Cuce et al. 2016). Use of solar energy for greenhouse crop production has made progress in many areas/countries (Farjana et al. 2018), including Australia, Japan (Cossu et al. 2017), Israel (Castello et al. 2017), and Germany (Schmidt et al. 2012), as well as developing countries such as Nepal (Fuller and Zahnd 2012) and India (Tiwari et al. 2016). In China, the installation of modern solar modules is expensive at present, with an estimated payback period of 9 years (Wang et al. 2017). We envision that as the cultivation system evolves with more advanced solar technology, the payback period will shorten.

Air temperatures inside and outside cluster facilities can range from 20 to $35{ }^{\circ} \mathrm{C}$ in cold winters in northern China. For example, in solar facilities at Lingyuan $\left(41^{\circ} 20^{\prime} \mathrm{N}, 119^{\circ}\right.$ $31^{\prime} \mathrm{E}$ ) in Liaoning province, northeastern China, in a $12-\mathrm{m}$ span, 5.5-m high, 65-m long solar greenhouse with heat storage-release systems, the night-time air temperature inside reached $13{ }^{\circ} \mathrm{C}$ while the outside was $-25.8^{\circ} \mathrm{C}$, a difference of $39^{\circ} \mathrm{C}$ (Sun et al. 2013).

The use of solar energy for food production is a significant feature of "Gobi agriculture" systems in northwest China. This differs from traditional greenhouses or glasshouses that require external energy inputs to grow crops, which can be economically and environmentally costly (Hassanien et al. 2016; Canakci et al. 2013; Wang et al. 2017). For example, the average annual electric energy consumption in conventional greenhouses can be more than $500 \mathrm{~kW} \mathrm{~h} \mathrm{~m}^{-2} \mathrm{y}^{-1}$ (Hassanien et al. 2016), with costs as high as USD $\$ 65,000$ 150,000 per year (in a Turkey case study) (Canakci et al. 2013). Globally, the expansion of conventional greenhouse- based crop production has been limited due to the intensive energy consumption and concerns about carbon emissions.

\subsection{Environmental benefits}

Heating agricultural greenhouses with fossil fuels, such as coal, oil, and natural gas, contributes to carbon emissions and climate change. Solar-powered Gobi land cultivation systems provide enhanced environmental benefits due to (i) reduced energy use, as crop cultivation relies entirely on solar power, unlike conventional glasshouses where power is supplied via electricity or natural gas that produces large greenhouse gas emissions; (ii) improved water-saving, as crop cultivation occurs under a plastic-covered roof with low soil evaporation and high ratio of transpiration: evaporation. Irrigation is monitored and controlled by a centralized computer that enables precise watering with minimal water loss; (iii) Reduced greenhouse gas emissions for the entire system (Chai et al. 2012) or the footprint per unit weight of the fresh vegetable based on life cycle assessment (Chai et al. 2014a). Crops grown in cluster facilities have significantly higher yields per unit of input (such as fertilizer, land use area) with more atmospheric $\mathrm{CO}_{2}$ converted to plant biomass through enhanced photosynthesis than open-field cultivation systems (Chang et al. 2013); and (iv) the use of compost substrates may increase soil carbon over time (Jaiarree et al. 2014; Chai et al. 2014a).

Some case studies have estimated net $\mathrm{CO}_{2}$ fixation by plants in solar-energy plastic cultivation systems at eight times higher than in traditional open-field systems (Wang et al. 
2011). More $\mathrm{CO}_{2}$ fixing in cultivation units means less $\mathrm{CO}_{2}$ emissions to the atmosphere (Wu et al. 2015). The magnitude of the effect varies with geographical location and the structure of cultivation units (Chai et al. 2014c). Studies have also demonstrated that facility cultivation allows plants to fix more $\mathrm{CO}_{2}$ from the atmosphere while emitting fewer greenhouse gases per $\mathrm{kg}$ of product (Chang et al. 2011). No additional heating is provided to the cultivation units, even during winter, saving about $750 \mathrm{Mg} \mathrm{ha}^{-1}$ of energy compared to conventional, coal-heated greenhouse production (Gao et al. 2010). Gobiland cultivation is a carbon-smart system for mitigating greenhouse gas emissions. However, life cycle assessments for facility cultivation are lacking in the literature, and more indepth research is required to assess the environmental impacts of these cultivation systems.

\subsection{Ecological benefits}

Northwestern China is rich in sunlight and heat resources with annual sunshine ranging from 2800 to $3300 \mathrm{~h}$. The development of clustered solar-energy Gobi land cultivation systems can turn light and heat resources into food production and offer significant ecological benefits, some of which are highlighted below.
First, Gobi land is used to produce quality crops for food security. In China, the average arable land per 100 capita is 8 ha (FAOSTAT 2014), significantly fewer than the 52 ha in the USA, 125 ha in Canada, and 214 ha in Australia. Cropland resources in China are decreasing rapidly due to rapid urbanization. Faced with limited arable land per capita, coupled with cropland being used for urban construction, China took the significant step of exploring the abundant Gobi land for crop cultivation (Jiang et al. 2014). Traditional agriculture is not possible on the desert-type, unproductive Gobi land (Fig. 6a). The construction of clustered cultivation facilities on Gobi land offers unique features for alleviating land conflicts between agriculture and other economic sectors (Fig. 6b) and helping secure food supply for the highly populated country.

Second, the production system mostly uses locally available resources. Each cultivation unit in the system is built and supported by frames made from wood, bamboo, or steel rods. During cold winters, locally made straw mats or thermal clothing blankets are rolled out on the sloped roof for additional insulation. The north walls of the cultivation units are also built using locally available materials, such as steel-framed and straw-stuffed blocks (Fig. 7a), sandbags (Fig. 7b), a stone-cement mixture (Fig. 7c), or common bricks (Fig. 7d).
Fig. 6 There are vast areas of Gobi land in northwest China that (a) was not possible previously to produce conventional crops, but (b) the construction of the clustered cultivation facilities makes the possibility into reality, alleviating the land use conflicts between agriculture and other economic sectors

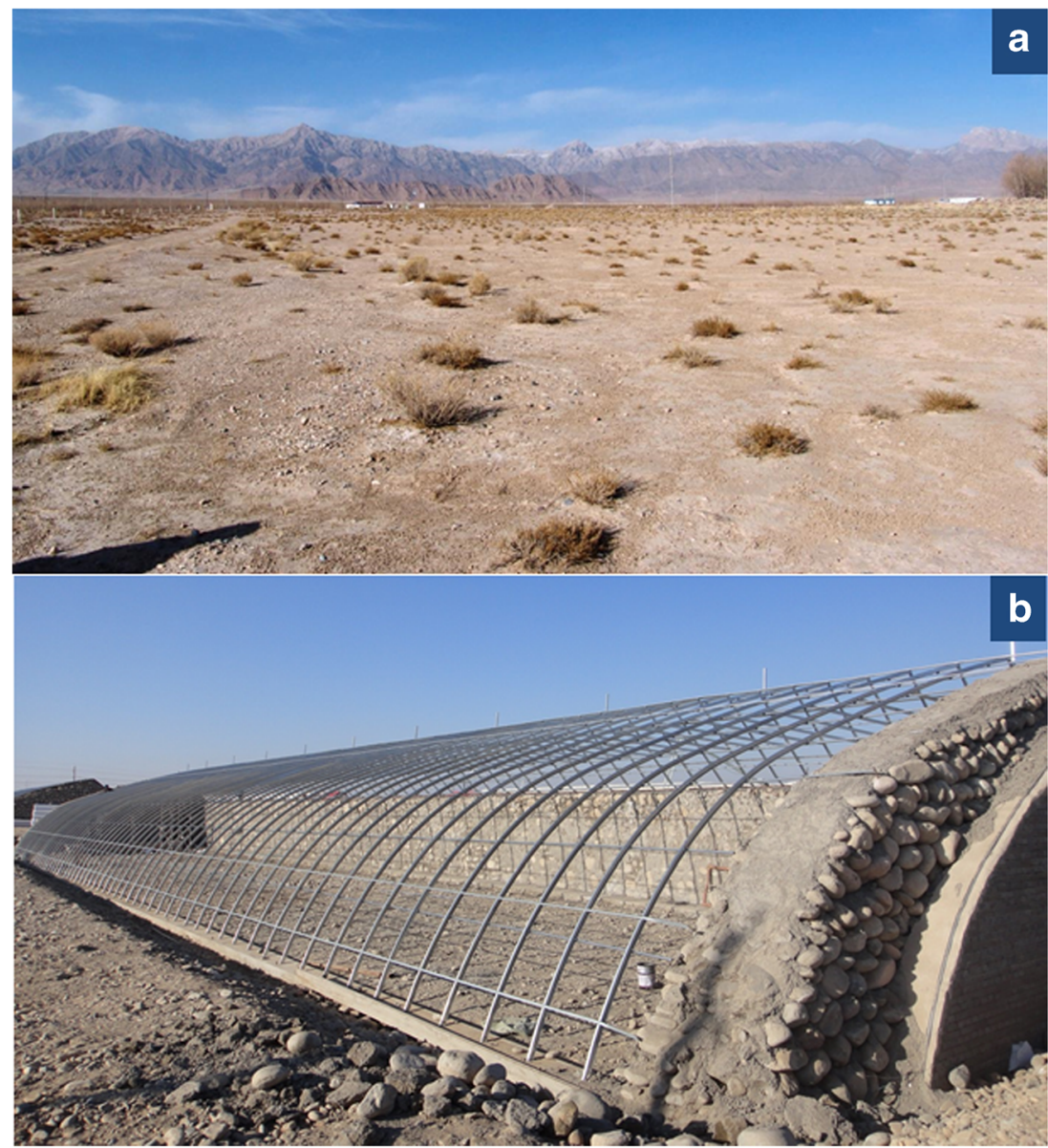


Fig. 7 Locally available materials are used to make the north wall of the cultivation units, including (a) steel-framed and straw-stuffed blocks, (b) sandbags, (c) stonecement mixture, and (d) common bricks, among others

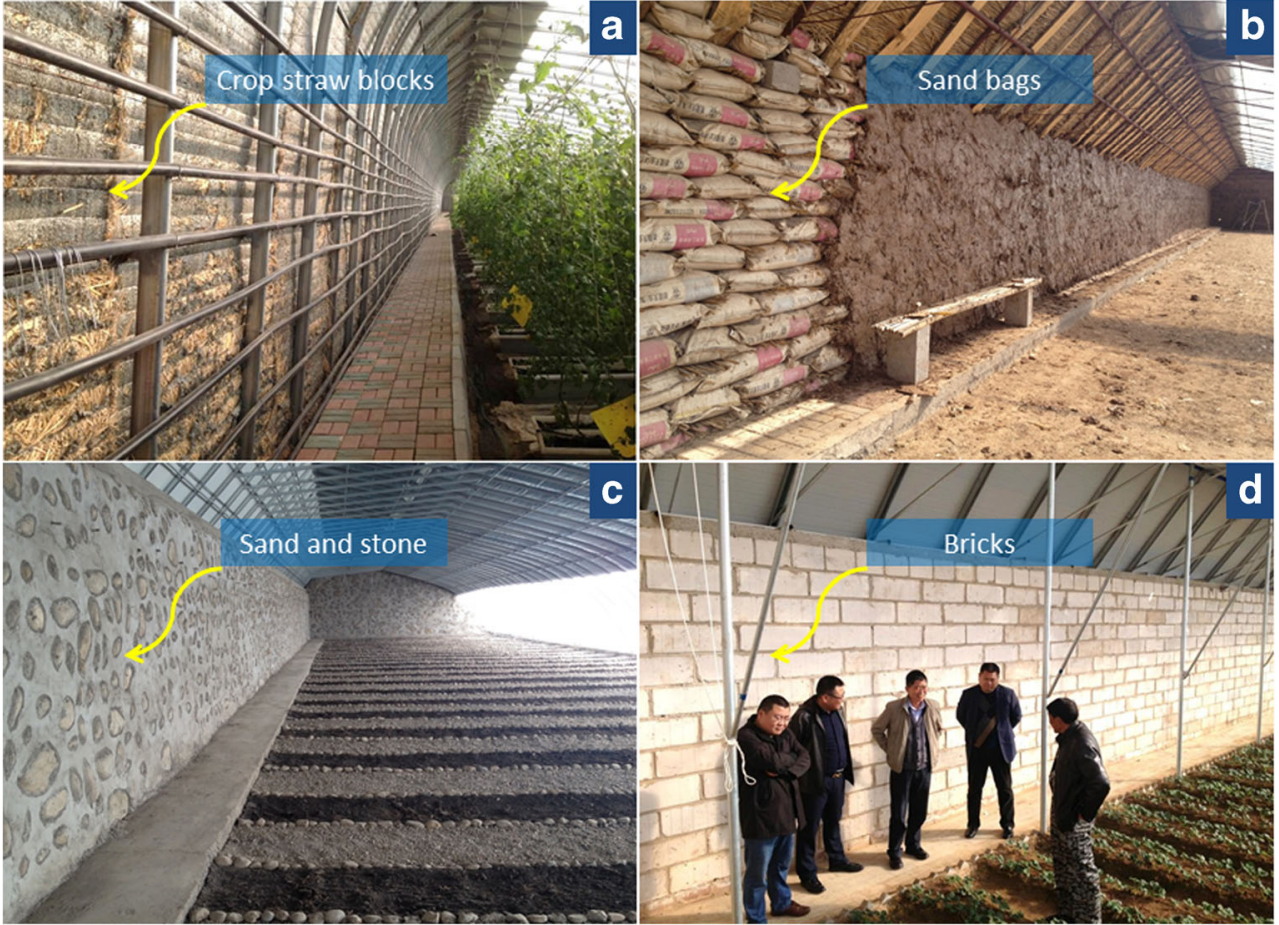

Locally available materials provide significant ecological and economic benefits because they can be obtained inexpensively or collected for free (e.g., stones and rocks in nearby desert areas), with minimal transport requirements. Also, the equipment for transporting materials, making substrates, and cultivating crops has gradually become available for cluster facility cultivation; this helps solve the agricultural labor shortage in some rural areas in China.

Third, this cultivation system provides opportunities for enhancing regional ecology. In a large part of northwestern China, Gobi land has no vegetation (Fig. 6a) resulting in fragile ecological environments. Wind erosion is common and becoming more severe with climate change. Frequent dust storms originate in the northwest often extending to other Asian regions. Development of solar energy clustered facility cultivation systems not only has the potential to simultaneously respond to the declining availability of suitable land in China, but plays a role in alleviating ecosystem fragility in the desert to arid environments in northwest China (Gao et al. 2010; Wang et al. 2017). The transformation of abandoned Gobi land into agricultural land may help to establish a new ecological system, which will change the primitive natural appearance and beautify the ecological environment.

\subsection{Effects on the stability of rural communities}

Socioeconomic development in northwestern China has lagged behind central and eastern regions, with many community districts below the national poverty level. Exploration of vast areas of Gobi land for fruit and vegetable production opens a door for this region to accelerate socioeconomic development. It turns the disadvantage of Gobi desertification into distinct regional economic advantages, not only promoting agricultural industry but driving other industries, which helps to stabilize rural communities. This low-cost agricultural system is becoming an important milestone for rallying rural communities.

The Gobi-land cultivation system stimulates food production and increases household income. In areas with temperatures above $-28{ }^{\circ} \mathrm{C}$ in winter, solar-powered greenhouses make full use of solar energy and non-arable land to produce fruit and vegetables throughout the year. Crops in clustered cultivation units yield significantly more than open-field production with a higher ratio of inputs to outputs. We analyzed the economic output in 14 studies with 120 solar-energy facility cultivation units (Xie et al. 2017) to find an average gross income of USD \$56,650 ha $\mathrm{ha}^{-1}$, being 10-30 times higher than that from open-field production at the same geological site. As a result, net profit from facility vegetable cultivation was 10-15 times greater than open-field vegetable production and 70-125 times greater than open-field maize (Zea mays) or wheat (Triticum aestivum) production.

The establishment of these new cultivation systems creates rural employment opportunities. Facility cultivation transforms the winter downtime into a busy, productive season, which creates rural employment opportunities, particularly in winter when farm families are often "home-alone" without employment. The production and marketing of fruit and vegetables are labor-intensive. Numerous rural laborers can be allocated to facility cultivation (Fig. 8a), while others can be 


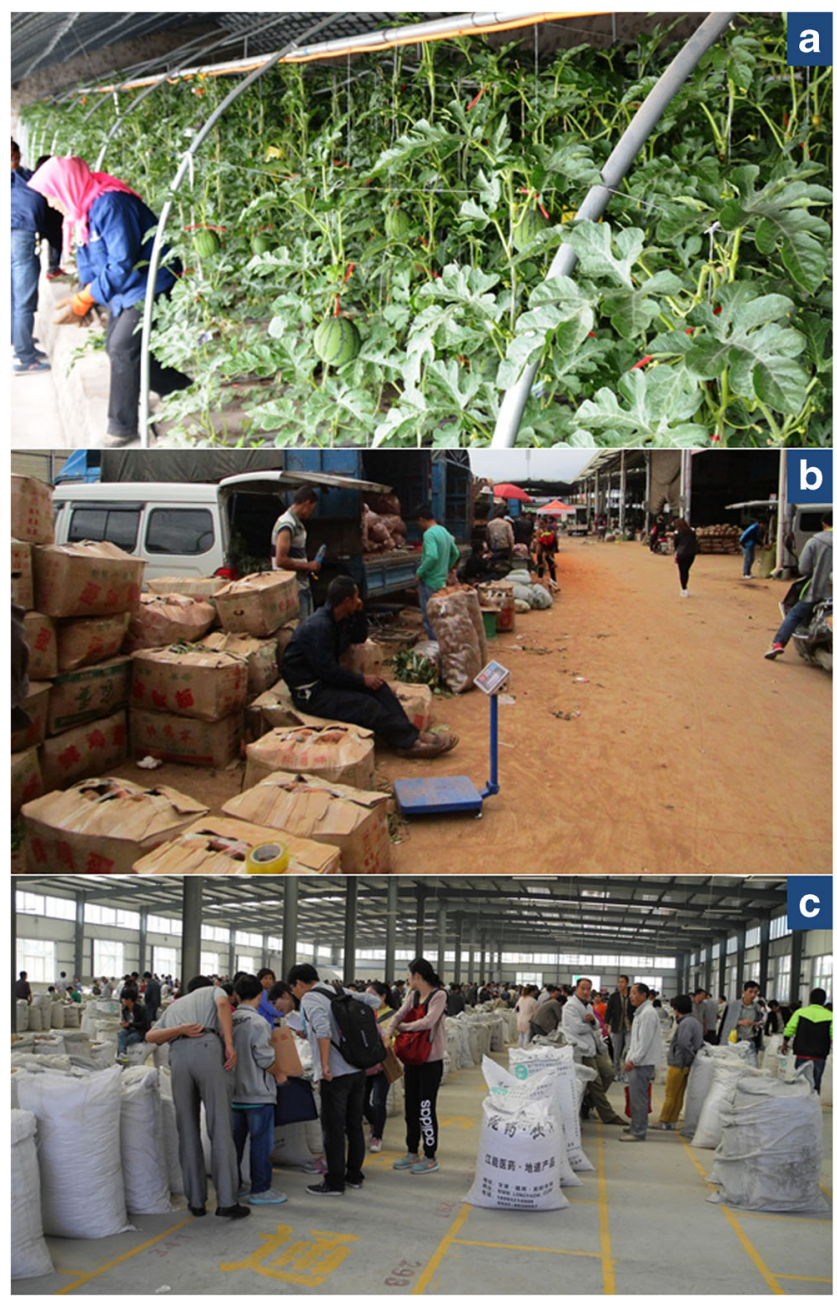

Fig. 8 Gobi land cultivation systems have the potential to create jobs that help enhance the rural community viability through (a) allocating a portion of the labor force to facility cultivation, (b) transporting and marketing fresh produce to the local or nearby communities, and (c) providing secondary employment opportunities in processing, storage, preservation, and sale of fresh produce

allocated to the transportation and marketing of produce to local or nearby communities (Fig. 8b). Most importantly, the processing, storage, preservation, and sale of fresh produce provide once-absent employment opportunities, which help to build a socially harmonious community (Fig. 8c) and rally rural community spirit.

There are no published reports on how the clustered cultivation system might affect rural community development. We suggest that these systems help the viability and stability of rural communities. The establishment of Gobi land cultivation systems enables agriculture in northwestern China to expand beyond the primary-production boundary. Consequently, community viability and long-term stability is enhanced because (i) new technologies are constantly developed to improve Gobi land cultivation, such as crop breeding, substrate development, and pest control measures, which become an important means for rural communities to develop in a sustainable manner; (ii) facility cultivation provides a yearround supply of fresh fruit and vegetables to the community, satisfying the increased requirements of middle-class citizens for more nutritional and healthy foods; and (iii) establishment of the new cultivation system helps to strengthen the internal cohesion of ethnic minority groups, as the citizens of ethnic minority groups require diverse foods with unique features, which are satisfied from the year-round fresh produce of the cultivation systems.

\section{Major challenges}

Gobi land cultivation systems have been evolving rapidly in China in recent years with the potential to expand facility areas and production levels (Jiang et al. 2015). However, some constraints and challenges need to be addressed.

\subsection{Water resource constraints}

One of the biggest challenges for agriculture in northwestern China is water shortages. Annual freshwater availability is low at $<760 \mathrm{~m}^{3}$ per capita $\mathrm{y}^{-1}$ (Chai et al. 2014b). In the Hexi Corridor of Gansu Province, annual precipitation is $<160 \mathrm{~mm}$ while annual evaporation is $>1500 \mathrm{~mm}$ (Deng et al. 2006). Many once-productive croplands along the Silk Road have been "paused" in recent years due to water shortages. Most open-field crop cultivation uses traditional "flooding" irrigation that exceeds $10,000 \mathrm{~m}^{3} \mathrm{ha}^{-1}$ per cropping season (Chai et al. 2016). Overexploitation of water resources is likely to further deteriorate the ecological environment and exhaust non-renewable groundwater resources (Martínez-Fernández and Esteve 2005). Vegetable production needs large amounts of water over a long growing period, and precipitation cannot meet the needs for optimal plant growth. In the Hexi Corridor of Gansu Province, where clustered facility cultivation systems have increased rapidly in recent years, the major source of water for all sectors originates from the accumulation of snow in the Qilian Mountain in winter, with summer snowmelt feeding the rivers and groundwater in the valleys (Chai et al. 2014b). In the last two decades, the measurable snow level on the Qilian Mountain has moved upwards at a rate of 0.2 to $1.0 \mathrm{~m}$ annually (Che and $\mathrm{Li} 2005$ ), while the underground water table in the valleys (supplied by water from the mountains) has persistently fallen, and the availability of groundwater has declined substantially (Zhang 2007). Consequently, some natural oases along the old Silk Road are gradually disappearing. Some excavation of water cellars has been used to save rainfall to provide supplementary water, but the efficacy is generally low. How to save water or enhance WUE in crop production is crucial for the long-term viability of Gobi land cultivation systems. 


\subsection{Fragile ecological environments}

In northwestern China, land endowment is poor. Mountains and valleys, along with oases and Gobi land, make for a complex ecological environment. Frequent drought and dust storms are worsening the ecological environment. About $88 \%$ of the total area of the Gansu Hexi Corridor has suffered desertification, and the line of desertification is moving southward to farmland. The natural conditions in the northwest region of China has been described as "wind blowing stones everywhere with grasses growing nowhere," a portrayal of the fragile ecological environment. Heavy pesticide use in facility cultivation is a potential environmental hazard and health hazard to workers. The lack of appropriate treatments for recycled organic substrates may pollute groundwater sources, bringing concerns for the general public.

\subsection{Labor resource constraints}

The labor supply to agriculture is generally low and insufficient, as more and more young workers move to cities to make a living, leading to a shortage of agricultural labor resources in rural areas. Current government policies to incentivize farmer willingness to cultivate cropland are not favorable for rural community development, which exacerbates the rural labor shortage. Also, the family farm as an independent farming unit remains the main mode of farm management, and the current governmental policies on land ownership may forbid farmers from buying and selling land, which could restrict extensive development of facility cultivation systems. Additionally, education levels in the northwest are generally lower than the central and eastern regions. The Central Government has implemented policies of compulsory education for the entire country, but many people in the northwest are unable to complete 9 years of education. All of the above may create an unfavorable environment for rural labor supply, which could hinder the extensive development of Gobi land facility systems.

\subsection{Economic sustainability}

With improvements in living standards, consumers demand a range of fresh produce of high quality and nutritional value. There is a large minority population (mainly with Hui and Dongxiang identities) in the northwest with a vegetabledominant dietary habit, which requires diverse products to meet their needs. This creates opportunities for new markets with new products. However, the market for fresh produce supplied by Gobi land cultivation systems could easily become saturated because the population of the six northwest provinces accounts for only $6.6 \%$ of the country's total, with an extremely low disposable income per capita. In 2012, the GDP per capita in the six northwest provinces averaged 26,733 Yuan (equivalent to USD \$4100), which was $31 \%$ below the country's average. Low income with few consumers may restrict the development of new markets in local areas and carry significant risks for economic sustainability in the long run. Studies are needed to investigate how sustainable this system could be, and what can be done to ensure its long-term economic sustainability. We realize that there is huge potential to market fresh produce to the highly populated central and eastern regions of the country. We suggest that priorities for market expansion focus on: (i) establishing so-called "dragon-chain" marketing logistics that links "cultivation-wholesalers-retailers-consumers" in a value chain; (ii) improving betweenregion transportation systems specific for the movement of agricultural products; and (iii) developing mechanisms for quality control, safety insurance, and fair pricing.

\subsection{Product quality and health}

Heavy metal concentrations are higher in some facility soils than in open fields. Facility-grown produce sometimes contains higher target hazard quotients of heavy metals than openfield vegetables (Chen et al. 2016), partly because human waste and other waste materials are incorporated in the substrates. In some facilities, excessive synthetic fertilizers as high as $670 \mathrm{~kg} \mathrm{~N} \mathrm{ha}^{-1}$, along with $1230 \mathrm{~kg} \mathrm{~N} \mathrm{ha}^{-1}$ from organic materials such as manures, are used annually for vegetable production (Gao et al. 2012). Additionally, the plastic film used for roof and ground cover in the cultivation units is often associated with esters of phthalic acids that are added during plastic film manufacture. There may be long-term health risks to growers exposed to the pollutant (Ma et al. 2015; Wang et al. 2015; Zhang et al. 2015). The levels of phthalates in Chinese soils are generally at the high end of the global range (Lü et al. 2018), and crops in heavily plasticized facilities may contain high levels of phthalates (Chen et al. 2016; Ma et al. 2015; Zhang et al. 2015). Worker exposure to phthalates may carry health risks (Lü et al. 2018). Research is needed to develop effective approaches to minimize phthalate concentrations in produce. The risk of trace amounts of phthalates to human health may be none or small but needs to be confirmed. The threshold levels of heavy metal concentrations need to be specified in end-products. Some sophisticated bioremediation methods may need to be developed for soil remediation of high metal pollution to minimize the effect of potential heavy metal concentration.

\section{Setting policies for sustainable development in Gobi land systems}

Clustered facility cultivation systems have been developing rapidly in northwestern China. In June 2017, about 3000 ha of Gobi land was under facility cultivation in Gansu Province alone. This area has geographical advantages for vegetable 
production, including long sunshine hours, large temperature differences between day and night, and clear sky with little/no air pollution. Facility cultivation systems are considered a "Gobi land miracle" for China's socioeconomic development. We recommend the following policy-setting priorities to ensure healthy development of the system with long-term stability.

\subsection{Balance between exploration and protection}

We suggest that policies are developed that focus on "protecting the ecological environment while exploring the new-found land," meaning that the development of Gobi land cultivation systems should not have negative environmental impacts. The policy should detail how to strengthen system productivity while promoting ecological sustainability. Environmental credits, "green insurance," and "green purchasing" should be considered and included in the evaluation of system sustainability. Policies are also needed for the use of chemical fertilizers, heavy metals and harmful substances, high residual pesticides, and plastic film recycling, among others. Some specific policies should be established to target key local issues. For example, water-reserving facilities should be constructed alongside facility cultivation units in the western end of Hexi Corridor where the currently available open-canal transport of water to irrigate the cultivation units carries significant risks of water loss during transportation and irrigation.

\subsection{Develop systematic measures for water use and water saving}

To make full use of the abundant Gobi land in northwestern China, a rigorous and pragmatic water use policy should be in place. Near-term priorities include: (i) water resource protection laws for "water measurement," "water drilling control," and "streams and springs authority" with detailed regulations on water rights, quotas, charges, and quality control; (ii) construction of water collection and storage facilities for rainwater using catchment cellar storage technology, optimized use of surface water resources, planned exploration of underground water, and implementation of a water intake permit system; (iii) strengthening the responsibilities of administrative agencies at all levels to control water allocation, eliminate water waste, and promote rational use of water resources; (iv) development of water-saving agricultural systems, including moving from flood or furrow irrigation to subsurface drip irrigation, using mulches to reduce evaporation, and improving field irrigation canal systems; and (v) for the long term, promotion of breeding for drought-tolerant cultivars, reforming farming systems, and improving infrastructure for facility construction.

\subsection{Strengthen agro-technology innovation}

Technology plays a vital role in the sustainable development of Gobi land cultivation systems; as such, a technology policy should cover: (i) construction of regional innovation centers and test stations, establishment of "target funding" specific for Gobi land cultivation systems to address urgent issues, and increased investment in research/demonstration and techinnovation platforms; (ii) development of technology extension systems - where government policies promote research institutions at all levels to carry out technology popularization - and establishment of local technology offices to carry out technical services in rural areas; (iii) adoption of measures to attract and retain employees to work in the underdeveloped northwest region; (iv) increasing farmer education levels beyond the compulsory 9 years, promotion of technological literacy in the rural population through vocational skills training, and nurturing a new generation of farmers to implement innovative agricultural technologies; and (v) development of special training programs by universities and research institutes for agricultural technology personnel to promote advanced technologies.

\subsection{Regulate the food chain}

The amount of fresh fruit and vegetables produced in clustered facilities is typically more than those needed by the local and nearby rural and urban communities. The timely transport of fresh produce to other domestic and overseas markets will ensure that production and marketing are balanced. Policies are needed to facilitate marketing mechanisms and logistics. Cultivars should be bred to meet the needs of a wide range of markets that cover a diverse range of products and tastes suited to different ethnic and religious groups. The policy should support wholesale markets, retail outlets, cold chain logistics, and information-monitoring systems. A policy may be needed for transportation systems, including the construction of mainline railways leading to central and eastern China, as well as access to overland channels in Russia, Outer Mongolia, Western Asia, and Europe.

\subsection{Cultivate professional farmers}

Farmers are the main players in rural socioeconomic development, but many young farmers have moved to cities for other income, leaving the cropland bare for years with little or no productivity in some areas (Seeberg and Luo 2018; Ye 2018). A policy is needed that supports increasing farm income from food production to encourage young farmers to stay on farms, which will ultimately improve the socioeconomic stability of rural communities. A key point of the policy should cultivate a new breed of farmers with improved qualifications and management skills, helping the potential move from traditional, self-sufficient, smaller-scale family farms to larger farm 
enterprises - an approach to develop modern agriculture in China. The current land policy may need to be renewed, allowing the skilled, professional farmers to expand their farms and optimize farm stewardship, where appropriate.

\subsection{Establish a sound social service system}

Rural communities in the northwest have been historically underdeveloped compared with central and eastern China. Policies are needed to establish effective social service systems that focus on improving education, health and employment, and enhancing the overall standard of living. Agriculture is the core business in rural communities. Policies are needed to encourage the development of large-sized agricultural cooperatives for effective use of land and water resources with increased income for farm families. For the Gobi-land cultivation system, a policy is needed to improve the efficiency of crop production, food processing, and product distribution at the local and nearby communities. An optimized layout/distribution of the cultivation facilities across the different eco-regions is needed to satisfy the diverse consumer needs for fresh fruit and vegetables at the regional/local level and to explore opportunities at the international level. A policy is also needed to ensure the safety and quality of produce from facility systems that details the storage, transport, and circulation of fresh produce out-of-season to minimize the risk of losing freshness and quality.

\section{Conclusions}

Land resources are central to agriculture and intrinsically linked to global challenges for food security and the livelihoods of millions of rural people. The world population is projected to reach 9.1 billion by 2050 and food production in developing countries needs to double from the 2015 level. Land resources are under heavy stress in developing countries due to rapid urbanization that competes for available land with agriculture. China has established new crop cultivation systems on Gobi land, namely "Gobi agriculture," which comprises a cluster of many (up to hundreds) individual cultivation units made from locally available materials and powered by solar energy. The plastic-roofed, greenhouse-like cultivation units produce high-quality fresh fruit and vegetables yearround. We estimate that these systems will cover about 2.2 million hectares by 2020 , becoming a cornerstone of food production in China's agricultural history. In this review, we identified some unique features of the cultivation systems, including increased land productivity per unit of input, improved WUE, and enhanced ecological and environmental benefits. This cultivation system offers excellent opportunities for exploring locally available resources to enrich rural people and ensure the long-term viability of rural communities. This system also faces significant challenges that need to be addressed.
We identified some key issues and their corresponding research priority areas for the near-term (3-5 years) that would help enhance the sustainability of this unique cultivation system. We strongly suggest that relevant governmental policies and social service systems in the rural areas are developed to ensure economic profitability and eco-environmental sustainability of Gobi-land cultivation systems.

Acknowledgments The authors would like to acknowledge all those who contributed their time and effort in participating in this research, and the staff at the Vegetable Technical Service Center of Suzhou District, Jiuquan, and the Wuwei Agricultural Extension Services, Wuwei, Gansu, for providing some data and photos presented in the article.

Funding This study was jointly funded by the "State Special Fund for Agro-Scientific Research in the Public Interest (grant number 201203001)," "China Agriculture Research Systems (grant number CARS-23-C-07)," "Gansu Province Science and Technology Key Project Fund (grant number 17ZD2NA015)," and "Special Fund for Science \& Technology Innovation and Development Guided by Gansu Province (grant number 2018ZX-02).”

\section{Compliance with ethical standards}

Conflict of interest The authors declare that they have no conflict of interest.

Open Access This article is distributed under the terms of the Creative Commons Attribution 4.0 International License (http:// creativecommons.org/licenses/by/4.0/), which permits unrestricted use, distribution, and reproduction in any medium, provided you give appropriate credit to the original author(s) and the source, provide a link to the Creative Commons license, and indicate if changes were made.

\section{References}

Çakir G, Ün C, Baskent EZ, Köse S, Sivrikaya F, Keleș S (2008) Evaluating urbanization, fragmentation and land use/land cover change pattern in Istanbul city, Turkey from 1971 to 2002. Land Degrad Dev 19:663-675. https://doi.org/10.1002/ldr.859

Canakci M, Yasemin Emekli N, Bilgin S, Caglayan N (2013) Heating requirement and its costs in greenhouse structures: a case study for Mediterranean region of Turkey. Renew Sustain Energy Rev 24: 483-490. https://doi.org/10.1016/j.rser.2013.03.026

Castello I, D’Emilio A, Raviv M, Vitale A (2017) Soil solarization as a sustainable solution to control tomato pseudomonads infections in greenhouses. Agron Sustain Dev 37:59. https://doi.org/10.1007/ s13593-017-0467-1

Chai L, Ma C, Ni JQ (2012) Performance evaluation of ground source heat pump system for greenhouse heating in northern China. Biosyst Eng 111:107-117. https://doi.org/10.1016/j.biosystemseng.2011.11.002

Chai L, Ma C, Liu M, Wang B, Wu Z, Xu Y (2014a) Carbon footprint of ground source heat pump system in heating solar greenhouse based on life cycle assessment. Trans Chinese Soc Agr Eng 30:149-155. https://doi.org/10.3969/j.issn.1002-6819.2014.08.018

Chai Q, Gan Y, Turner NC, Zhang RZ, Yang C, Niu Y, Siddique KHM (2014b) Water-saving innovations in Chinese agriculture. Adv Agron 126:149-201. https://doi.org/10.1007/s13593-015-0338-6

Chai Q, Qin AZ, Gan YT, Yu AZ (2014c) Higher yield and lower carbon emission by intercropping maize with rape, pea, and wheat in arid 
irrigation areas. Agron Sustain Dev 34:535-543. https://doi.org/10. 1007/s13593-013-0161-X

Chai Q, Gan Y, Zhao C, Xu HL, Waskom RM, Niu Y, Siddique KHM (2016) Regulated deficit irrigation for crop production under drought stress. A review. Agron Sustain Dev 36:1-21. https://doi. org/10.1007/s13593-015-0338-6

Chang J, Wu X, Liu A, Wang Y, Xu B, Yang W, Meyerson LA, Gu B, Peng C, Ge Y (2011) Assessment of net ecosystem services of plastic greenhouse vegetable cultivation in China. Ecol Econ 70: 740-748. https://doi.org/10.1016/j.ecolecon.2010.11.011

Chang J, Wu X, Wang Y, Meyerson LA, Gu B, Min Y, Xue H, Peng C, Ge Y (2013) Does growing vegetables in plastic greenhouses enhance regional ecosystem services beyond the food supply? Front Ecol Environ 11:43-49. https://doi.org/10.1890/100223

Che T, Li X (2005) Spatial distribution and temporal variation of snow water resources in China during 1993-2002. J Glaciol Geocryol 27: 64-67

Chen C, Li Z, Guan Y, Han Y, Ling H (2012) Effects of building methods on thermal properties of phase change heat storage composite for solar greenhouse. Trans Chinese Soc Agr Eng 28:186-191. https:// doi.org/10.3969/j.issn.1002-6819.2012.z1.032

Chen J, Kang S, Du T, Qiu R, Guo P, Chen R (2013) Quantitative response of greenhouse tomato yield and quality to water deficit at different growth stages. Agric Water Manag 129:152-162. https:// doi.org/10.1016/j.agwat.2013.07.011

Chen Z, Tian T, Gao L, Tian Y (2016) Nutrients, heavy metals and phthalate acid esters in solar greenhouse soils in Round-Bohai Bay-Region, China: impacts of cultivation year and biogeography. Environ Sci Pollut Res 23:13076-13087. https://doi.org/10.1007/ s11356-016-6462-2

Cossu M, Ledda L, Urracci G, Sirigu A, Cossu A, Murgia L, Pazzona A, Yano A (2017) An algorithm for the calculation of the light distribution in photovoltaic greenhouses. Sol Energy 141:38-48. https:// doi.org/10.1016/j.solener.2016.11.024

Cuce E, Cuce PM, Young CH (2016) Energy saving potential of heat insulation solar glass: key results from laboratory and in-situ testing. Energy 97:369-380. https://doi.org/10.1016/j.energy.2015.12.134

de Grassi A, Salah Ovadia J (2017) Trajectories of large-scale land acquisition dynamics in Angola: diversity, histories, and implications for the political economy of development in Africa. Land Use Policy 67:115-125. https://doi.org/10.1016/j.landusepol.2017.05.032

Deng XP, Shan L, Zhang H, Turner NC (2006) Improving agricultural water use efficiency in arid and semiarid areas of China. Agric Water Manag 80:23-40. https://doi.org/10.1016/j.agwat.2005.07.021

Du S, Ma Z, Xue L (2016) Optimal drip fertigation amount improving muskmelon yield, quality and use efficiency of water and nitrogen in plastic greenhouse of gravel-mulched field. Trans Chinese Soc Agr Eng 32:112-119. https://doi.org/10.11975/j.issn.1002-6819.2016. 05.016

FAOSTAT (2014) FAO statistical yearbooks - world food and agriculture. Food and Agriculture Organization of the United Nations 2013. https://doi.org/10.1073/pnas.1118568109

Farjana SH, Huda N, Mahmud MAP, Saidur R (2018) Solar process heat in industrial systems - a global review. Renew Sustain Energy Rev 82:2270-2286. https://doi.org/10.1016/j.rser.2017.08.065

Fu GH, Liu WK (2016) Effects on cooling down and increasing yield of sweet pepper of a novel cultivation method: soil ridge substrateembedded in Chinese solar greenhouse. Chin J Agrometeorol 37: 199-205. https://doi.org/10.3969/j.issn.1000-6362.2016.02.09

Fu H, Zhang G, Zhang F, Sun Z, Geng G, Li T (2017) Effects of continuous tomato monoculture on soil microbial properties and enzyme activities in a solar greenhouse. Sustainability (Switzerland) 9 . https://doi.org/10.3390/su9020317

Fu G, Li Z, Liu W, Yang Q (2018) Improved root zone temperature buffer capacity enhancing sweet pepper yield via soil-ridged substrate- embedded cultivation in solar greenhouse. Int J Agric Biol Eng 11: 41-47. https://doi.org/10.25165/j.ijabe.20181102.2679

Fuller R, Zahnd A (2012) Solar greenhouse technology for food security: a case study from Humla District, NW Nepal. Mt Res Dev 32:411419. https://doi.org/10.1659/MRD-JOURNAL-D-12-00057.1

Gao LH, Qu M, Ren HZ, Sui XL, Chen QY, Zhang ZX (2010) Structure, function, application, and ecological benefit of a single-slope, energy-efficient solar greenhouse in China. HortTechnology 20: 626-631

Gao JJ, Bai XL, Zhou B, Zhou JB, Chen ZJ (2012) Soil nutrient content and nutrient balances in newly-built solar greenhouses in northern China. Nutr Cycl Agroecosyst 94:63-72. https://doi.org/10.1007/ s10705-012-9526-9

Godfray HCJ (2011) Food and biodiversity. Science 333:1231-1232. https://doi.org/10.1126/science.1211815

Godfray HCJ, Beddington JR, Crute IR, Haddad L, Lawrence D, Muir JF, Pretty J, Robinson S, Thomas SM, Toulmin C (2010) Food security: the challenge of feeding 9 billion people. Science 327:812-818. https://doi.org/10.1126/science.1185383

Guan Y, Chen C, Li Z, Han Y, Ling H (2012) Improving thermal environment in solar greenhouse with phase-change thermal storage wall. Trans Chinese Soc Agr Eng 28:194-201. https://doi.org/10. 3969/j.issn.1002-6819.2012.10.031

Guan Y, Chen C, Ling H, Han Y, Yan Q (2013) Analysis of heat transfer properties of three-layer wall with phase-change heat storage in solar greenhouse. Trans Chinese Soc Agr Eng 29:166-173. https://doi. org/10.3969/j.issn.1002-6819.2013.21.021

Halicki W, Kulizhsky SP (2015) Changes in arable land use in Siberia in the 20th century and their effect on soil degradation. Int J Environ Stud 72:456-473. https://doi.org/10.1080/00207233.2014.990807

Han Y, Xue X, Luo X, Guo L, Li T (2014) Establishment of estimation model of solar radiation within solar greenhouse. Trans Chinese Soc Agr Eng 30:174-181. https://doi.org/10.3969/j.issn.1002-6819. 2014.10.022

Hassanien RHE, Li M, Dong Lin W (2016) Advanced applications of solar energy in agricultural greenhouses. Renew Sustain Energy Rev 54:989-1001. https://doi.org/10.1016/j.rser.2015.10.095

Jaiarree S, Chidthaisong A, Tangtham N, Polprasert C, Sarobol E, Tyler SC (2014) Carbon budget and sequestration potential in a sandy soil treated with compost. Land Degrad Dev 25:120-129. https://doi. org/10.1002/ldr.1152

Jiang D, Hao M, Fu J, Zhuang D, Huang Y (2014) Spatial-temporal variation of marginal land suitable for energy plants from 1990 to 2010 in China. Sci Rep 4:e5816. https://doi.org/10.1038/srep05816

Jiang W, Deng J, Yu H (2015) Development situation, problems and suggestions on industrial development of protected horticulture. Sci Agric Sin 48:3515-3523

Kraemer R, Prishchepov AV, Müller D, Kuemmerle T, Radeloff VC, Dara A, Terekhov A, Frühauf M (2015) Long-term agricultural landcover change and potential for cropland expansion in the former virgin lands area of Kazakhstan. Environ Res Lett 10. https://doi. org/10.1088/1748-9326/10/5/054012

Li Z, Wang T, Gong Z, Li N (2013) Forewarning technology and application for monitoring low temperature disaster in solar greenhouses based on Internet of things. Trans Chinese Soc Agr Eng 29:229 236. https://doi.org/10.3969/j.issn.1002-6819.2013.04.029

Li Y, Niu W, Xu J, Zhang R, Wang J, Zhang M (2016) Aerated irrigation enhancing quality and irrigation water use efficiency of muskmelon in plastic greenhouse. Trans Chinese Soc Agr Eng 32:147-154. https://doi.org/10.11975/j.issn.1002-6819.2016.01.020

Liang X, Gao Y, Zhang X, Tian Y, Zhang Z, Gao L (2014) Effect of optimal daily fertigation on migration of water and salt in soil, root growth and fruit yield of cucumber (Cucumis sativus L.) in solargreenhouse. PLoS One 9:e86975. https://doi.org/10.1371/journal. pone. 0086975 
Ling H, Weijiao S, Su LY, Yan Y, Xianchang Y, Chaoxing H (2015) Changes of organic soil substrate with continuous vegetable cultivation in solar greenhouse. Acta Hortic (1107):157-163. https://doi. org/10.17660/ActaHortic.2015.1107.21

Liu J, Zhang Z, Xu X, Kuang W, Zhou W, Zhang S, Li R, Yan C, Yu D, Wu S, Jiang N (2010) Spatial patterns and driving forces of land use change in China during the early 21 st century. J Geogr Sci 20:483494. https://doi.org/10.1007/s11442-010-0483-4

Liu Y, Yang Y, Li Y, Li J (2017) Conversion from rural settlements and arable land under rapid urbanization in Beijing during 1985-2010. J Rural Studies 51:141-150. https://doi.org/10.1016/j.jrurstud.2017.02.008

Lü H, Mo CH, Zhao HM, Xiang L, Katsoyiannis A, Li YW, Cai QY, Wong MH (2018) Soil contamination and sources of phthalates and its health risk in China: a review. Environ Res 164:417-429. https:// doi.org/10.1016/j.envres.2018.03.013

Ma TT, Wu LH, Chen L, Zhang HB, Teng Y, Luo YM (2015) Phthalate esters contamination in soils and vegetables of plastic film greenhouses of suburb Nanjing, China and the potential human health risk. Environ Sci Pollut Res 22:12018-12028. https://doi.org/10. 1007/s11356-015-4401-2

Martínez-Fernández J, Esteve MA (2005) A critical view of the desertification debate in southeastern Spain. Land Degrad Dev 16:529 539. https://doi.org/10.1002/ldr.707

Mueller ND, Gerber JS, Johnston M, Ray DK, Ramankutty N, Foley JA (2012) Closing yield gaps through nutrient and water management. Nature 490:254-257. https://doi.org/10.1038/nature11420

Romero P, Martinez-Cutillas A (2012) The effects of partial root-zone irrigation and regulated deficit irrigation on the vegetative and reproductive development of field-grown Monastrell grapevines. Irrig Sci 30:377-396. https://doi.org/10.1007/s00271-012-0347-z

Schmidt U, Schuch I, Dannehl D, Rocksch T, Salazar-Moreno R, RojanoAguilar A, López-Cruz IL (2012) The closed solar greenhouse technology and evaluation of energy harvesting under summer conditions. Acta Hortic 932:433-440. https://doi.org/10.17660/ActaHortic.2015.1107.21

Seeberg V, Luo S (2018) Migrating to the City in north West China: young rural Women's empowerment. J Human Dev Capab 19: 289-307. https://doi.org/10.1080/19452829.2018.1430752

Song WJ, He CX, Yu XC, Zhang ZB, Li YS, Yan Y (2013) Changes of organic soil substrate properties with different cultivation years and their effects on cucumber growth in solar greenhouse. Chin J Appl Ecol 24:2857-2862

Sun Z, Huang W, Li T, Tong X, Bai Y, Ma J (2013) Light and temperature performance of energy-saving solar greenhouse assembled with color plate. Trans Chinese Soc Agr Eng 29:159-167. https://doi.org/10. 3969/j.issn.1002-6819.2013.19.020

Tiwari S, Tiwari GN, Al-Helal IM (2016) Development and recent trends in greenhouse dryer: a review. Renew Sustain Energy Rev 65:10481064. https://doi.org/10.1016/j.rser.2016.07.070

Tong G, Christopher DM, Li T, Wang T (2013) Passive solar energy utilization: a review of cross-section building parameter selection for Chinese solar greenhouses. Renew Sustain Energy Rev 26: 540-548. https://doi.org/10.1016/j.rser.2013.06.026

Wang HX, Xu HB (2016) A reliability research on internet of objects monitoring system of facility agriculture. Key Eng Mater 693:1486$1491 \mathrm{https} / / /$ doi.org/scientific.net/KEM.693.1486

Wang F, Du T, Qiu R, Dong P (2010) Effects of deficit irrigation on yield and water use efficiency of tomato in solar greenhouse. Trans Chinese Soc Agr Eng 26:46-52. https://doi.org/10.3969/j.issn. 1002-6819.2010.09.008

Wang Y, Xu H, Wu X, Zhu Y, Gu B, Niu X, Liu A, Peng C, Ge Y, Chang J (2011) Quantification of net carbon flux from plastic greenhouse vegetable cultivation: a full carbon cycle analysis. Environ Pollut 159:1427-1434. https://doi.org/10.1016/j.envpol.2010.12.031

Wang Y, Liu F, Jensen CR (2012) Comparative effects of deficit irrigation and alternate partial root-zone irrigation on xylem $\mathrm{pH}, \mathrm{ABA}$ and ionic concentrations in tomatoes. J Exp Bot 63:1907-1917. https:// doi.org/10.1093/jxb/err370

Wang J, Li S, Guo S, Ma C, Wang J, Jin S (2014) Simulation and optimization of solar greenhouses in Northern Jiangsu Province of China. Energy Buildings 78:143-152. https://doi.org/10.1016/j. enbuild.2014.04.006

Wang J, Chen G, Christie P, Zhang M, Luo Y, Teng Y (2015) Occurrence and risk assessment of phthalate esters (PAEs) in vegetables and soils of suburban plastic film greenhouses. Sci Total Environ 523: 129-137. https://doi.org/10.1016/j.scitotenv.2015.02.101

Wang T, Wu G, Chen J, Cui P, Chen Z, Yan Y, Zhang Y, Li M, Niu D, Li $B$, Chen H (2017) Integration of solar technology to modern greenhouse in China: current status, challenges and prospect. Renew Sustain Energy Rev 70:1178-1188. https://doi.org/10.1016/j.rser. 2016.12.020

Wu X, Ge Y, Wang Y, Liu D, Gu B, Ren Y, Yang G, Peng C, Cheng J, Chang J (2015) Agricultural carbon flux changes driven by intensive plastic greenhouse cultivation in five climatic regions of China. J Clean Prod 95:265-272. https://doi.org/10.1016/j.jclepro.2015.02.083

Xie J, Yu J, Chen B, Feng Z, Li J, Zhao C, Lyu J, Hu L, Gan Y, Siddique KHM (2017) Facility cultivation systems “设施农业” - a Chinese model for the planet. Adv Agron 145:1-42. https://doi.org/10. 1016/bs.agron.2017.05.005

Xu H, Wang X, Xiao G (2000) A remote sensing and GIS integrated study on urbanization with its impact on arable lands: Fuqing City, Fujian Province, China. Land Degrad Dev 11:301-314. https://doi.org/10. 1002/1099-145X(200007/08)11:4<301::AID-LDR392>3.0.CO;2-N

$\mathrm{Xu} \mathrm{H}$, Zhao L, Tong G, Cui Y, Li T (2013) Microclimate variations with wall configurations for Chinese solar greenhouses. Appl Mech Mater 291294:931-937 https://doi.org/scientific.net/AMM.291-294.931

Xu J, Li Y, Wang RZ, Liu W (2014) Performance investigation of a solar heating system with underground seasonal energy storage for greenhouse application. Energy 67:63-73. https://doi.org/10.1016/j. energy.2014.01.049

Yang H, Du T, Qiu R, Chen J, Wang F, Li Y, Wang C, Gao L, Kang S (2017) Improved water use efficiency and fruit quality of greenhouse crops under regulated deficit irrigation in Northwest China. Agric Water Manag 179:193-204. https://doi.org/10.1016/j.agwat.2016.05.029

Ye J (2018) Stayers in China's "hollowed-out" villages: a counter narrative on massive rural-urban migration. Popul Space Place 24:e2128. https://doi.org/10.1002/psp.2128

Yuan H, Wang H, Pang S, Li L, Sigrimis N (2013) Design and experiment of closed culture system for solar greenhouse. Trans Chin Soc Agric Eng 29:159-165. https://doi.org/10.3969/j.issn.1002-6819.2013.21.020

Zhang J (2007) Barriers to water markets in the Heihe River basin in Northwest China. Agric Water Manag 87:32-40. https://doi.org/ 10.1016/j.agwat.2006.05.020

Zhang Y, Zou Z, Li J (2014) Performance experiment on lighting and thermal storage in tilting roof solar-greenhouse. Trans Chinese Soc Agr Eng 30:129-137. https://doi.org/10.3969/j.issn.1002-6819. 2014.01.017

Zhang Y, Wang P, Wang L, Sun G, Zhao J, Zhang H, Du N (2015) The influence of facility agriculture production on phthalate esters distribution in black soils of Northeast China. Sci Total Environ 506-507: 118-125. https://doi.org/10.1016/j.scitotenv.2014.10.075

Zhang W, Cao G, Li X, Zhang H, Wang C, Liu Q, Chen X, Cui Z, Shen J, Jiang R, Mi G, Miao Y, Zhang F, Dou Z (2016) Closing yield gaps in China by empowering smallholder farmers. Nature 537:671-674. https://doi.org/10.1038/nature19368

Zhang J, Wang J, Guo S, Wei B, He X, Sun J, Shu S (2017) Study on heat transfer characteristics of straw block wall in solar greenhouse. Energy Buildings 139:91-100. https://doi.org/10.1016/j.enbuild.2016.12.061

Zhou S, Zhang Y, Yang Q, Cheng R, Fang H, Ke X, Lu W, Zhou B (2016) Performance of active heat storage-release unit assisted with a heat pump in a new type of Chinese solar greenhouse. Appl Eng Agric 32:641-650. https://doi.org/10.13031/aea.32.11514 